UDC 78.087.6

DOI 10.33287/221931

Guzhva Alexander

candidate of Arts, doctor of philosophy, professor, the head of the ,Vocal-Choral mastery" chair for M. Glinka academy music of Dnepropetrovsk region тел: (066) 633 - 42 - 01 e-mail: guzhva07@meta.ua

Mykolaichuk Nadiia Master of ,, Vocal-Choral mastery" chair of M. Glinka Dnipropetrovsk Academy of music тел. (095) 095-98-67 e-mail: nadia000m@gmail.com

\title{
INTERPRETATION OF BAROQUE VOCAL MUSIC AT THE CONTEMPORARY STAGE
}

The purpose of the article is to identify the specificities of teaching the interpretation of vocal pieces of music of the Baroque era, based on the relevant literature and experience of baroque master classes of contemporary performers. The author focuses on the performance requirements to vocalists, which comply with the particular interpretation features of the baroque score, in terms of historically informed and technical performance. The methods in the proposed research is based on the use of empirical approaches, namely observation and generalization of vocalist's performance tasks, as well as analytical method in performance analysis of pieces of music (intonation and structural analysis), and revealing the value of the baroque repertoire in the process of becoming a modern vocalist. Applied methods reveal the practical performing aspect of the study. The scientific novelty of the article is to identify and summarize the main factors and techniques of training that become necessary for modern performers of baroque vocal music, influencing the formation of a vocalist and the further performance of another vocal repertoire. This question is considered from the singer-performer's point of view the application of the rules and traditions of baroque performance in modern conditions. Both the works of composers and the methodological literature of the Baroque era, as well as the experience of contemporary 
recognized singers, the personal experience of the author as a singerperformer of baroque music, and pieces of music, are in the field of view. In the conclusions it is noted that the broad analysis of pieces of music, involved in performing practice, makes it possible to reveal the existence of important requirements for vocalists in the Baroque art, from which both the musical aesthetics of the Baroque and the tradition of baroque performance gradually grew.

The key words: Baroque operas, interpretation, style, training of modern vocalists, sound formation, theory of affects, ornamentation of melody.

Гужва Олександр Павлович, кандидат мистецтвознавства, доктор філософських наук, професор, завідувач кафедри „Вокальнохорова майстерність” Дніпропетровської академії музики ім. М. Глінки

Миколайчук Надія Вікторівна, магістрант кафедри „Вокально-хорова майстерність” Дніпропетровської академії музики ім. М. Глінки

Інтерпретація вокальної музики епохи бароко на сучасному eтапі

Мета статті - виявлення специфіки інтерпретації вокальних творів епохи бароко. У центрі уваги - виконавські вимоги до вокаліста, що відповідають особливості трактування барокової партитури, 3 точки зору історично інформованого виконавства. Методи пропонованого дослідження грунтуються на застосуванні емпіричних підходів, а саме - спостереженні та узагальненні виконавських завдань вокаліста, а також аналітичному методі, що застосовується при виконавському аналізі творів (інтонаційний i структурний аналіз), та виявленні значення барокового репертуару в процесі становлення сучасного вокаліста. Застосовані методи розкривають практичний виконавський аспект дослідження. Наукова новизна статті полягає у виявленні та узагальненні основних факторів і прийомів навчання, що стають необхідними для сучасних виконавців барокової вокальної музики й впливають на становлення вокаліста та на подальше виконання іншого вокального репертуару. Вказане питання розглядається 3 позиції вокаліста-виконавця застосування правил і традицій барокового виконавства у сучасних умовах. У поле зору потрапили як праці композиторів і методична література епохи бароко, так і безпосередньо досвід сучасних 
визнаних співаків, особистий досвід автора статті як вокаліставиконавця барокової музики. У висновках зазначено, що саме широкий аналіз творів, залучених у виконавську практику, дає можливість виявити існування в мистецтві доби бароко важливих вимог до виконавців-вокалістів, 3 яких поступово зростала як сама музична естетика бароко, так і традиції барокового виконавства.

Ключові слова: барокові опери, інтерпретація, стиль, навчання сучасних вокалістів, звукоутворення, теорія афектів, орнаментація мелодії.

Гужва Александр Павлович, кандидат искусствоведения, доктор философских наук, профессор, заведующий кафедрой „Вокально-хоровое мастерство” Днепропетровской академии музыки им. М. Глинки

Миколайчук Надежда Викторовна, магистрант кафедры „Вокально-хоровое мастерство” Днепропетровской академии музыки им. М. Глинки

Интерпретация вокальной музыки эпохи барокко на современном этапе

Цель статьи - выявление специфики интерпретации вокальных произведений эпохи барокко. В центре внимания автора исполнительские требования к вокалисту, соответствующие особенности трактовки барочной партитуры, с точки зрения исторически информированного исполнения. Методы исследования основываются на применении эмпирических подходов, а именно наблюдении и обобщении исполнительских задач вокалиста, а также аналитическом методе при создании исполнительского анализа произведений (интонационный и структурный анализ), а также выявлении значения барочного репертуара в процессе становления современного вокалиста. Применяемые методы раскрывают практический исполнительский аспект исследования. Научная новизна статьи заключается в выявлении и обобщении основных факторов и приемов обучения, которые становятся необходимыми для современных исполнителей барочной вокальной музыки, влияющие на становление вокалиста и на дальнейшее исполнение иного вокального репертуара. Указанный вопрос рассматривается с позиции вокалиста-исполнителя - применение правил и традиций барочного исполнительства в современных условиях. В поле зрения попали как работы композиторов и методическая литература эпохи 
барокко, так и непосредственно опыт современных признанных певцов, личный опыт автора статьи в качестве вокалиста-исполнителя барочной музыки. В выводах отмечается, что именно широкий анализ произведений, вовлеченных в исполнительскую практику, даёт возможность выявить существование в искусстве эпохи барокко важных требований к исполнителям-вокалистам, из которых постепенно росла как сама музыкальная эстетика барокко, так и традиции барочного исполнительства.

Ключевые слова: барочные оперы, интерпретация, стиль, обучение современных вокалистов, звукообразование, теория аффектов, орнаментация мелодии.

The statement of the problem. Unfortunately, in Ukraine there is no specialized vocal educational institution dedicated to performing ancient vocal music, we do not know enough stylistic subtleties of baroque singing, so to help us there are more narrowly directed baroque master classes that can set the right direction of voice development and singing style manner.

The topicality of this exploration is denoted by the fact that in the programs of competitions and festivals baroque pieces of music are often defined as mandatory, this music is widespread on the stages of Europe and America, baroque operas and concerts are held constantly. Performing vocal music of this era requires the study of baroque vocal art aspects, which will allow the performer to show his personality and be a competitive participant in the relevant events.

The analysis of the literatures. Experience of live baroque master class by O. Pasichnyk provides valuable information for vocalistsperformers [2]. The involvement of the book by N. Arnucour „Music in the language of sounds, the path to a new understanding of music" [1] was important for us in the discovery of our theme. This work gave us the opportunity to realize that a sense of style is born exactly from a musical score, because both the presentation of the material and directly the expressiveness of sounds lead to understanding of the piece of music content, and the Baroque teaches us to connect our feelings with what the music itself brings. Book by P. Barbier „Venice of Vivaldi. Music and Holidays of the Baroque Era" [3] introduces us to the atmosphere of performance, and indicates that music becomes an integral part of people's mind, it becomes the language of human feelings. From the book by A. Beyshlag „Ornamentation in Music" [4] we learn about the rules of 
ornamentation in Baroque music. P.V. Lutsker, I.P. Susidko in the book „The Italian Opera of the Eighteenth Century" [5] create a historical panorama of the Italian opera in the 18th century. In particular, it is a question of the Arcadian school activity, which brought together composers from different national schools and indicated an important tendency in the development of music, when individual achievements were enriched by joint composers' reflections on the essence of music, the construction of opera and musical language.

The purpose of this article is to identify the specificities of teaching the interpretation of vocal pieces of music of the Baroque era based on baroque master classes of modern performers.

The object of this investigation is the baroque singing tradition.

The subject of represented exploration is the performing traditions interpretation of baroque vocal music by contemporary performers.

The basic material. The modern listener perceives Baroque music and baroque performance through the prism of the acquired auditory experience of various subsequent musical styles that Baroque musicians did not have yet. Therefore, the main task of modern artists in the performance of this music, first and foremost, is the creation of the very Baroque era spirit. This concept includes both cultural and historical conditions and worldview convictions, and of course, the technological methods, which are necessary for the most accurate authentic performance. These requirements include melisms deciphering rules in notes, correct dynamics distribution within the whole with the presence of terraced sounds, "echo" technique, the use of special sound-producing methods, melodies ornamentation rules in arias by reprise in the section Da Capo [5, 304]. Mannheim school, which enriched the dynamics of sounding, and thus having gone beyond the "forte", gave an idea of the world infinity, creating a new dimension of a human understanding itself: besides the gods, it began to carry the infinity of the universe and its greatness.

When comparing modern and Baroque worldview convictions, we pay attention to different understanding of Time. Baroque is characterized by a prolonged stay within one emotional state, a deeper, all-consuming penetration into the finest subtleties of human feelings, which is accordingly accompanied by richer palette of voice timbre tones. However, in our modern life, Time has a different value because of the ever-changing series of events. Haste steals many important and profound aspects, to which the Baroque on the contrary is sensitive and careful. Immersion in emotion gives you the opportunity to find the means of 
expression that contribute to the disclosure of emotional state. The Baroque era created a connection between the means of expression and emotions, because emotions brought to life rhetorical figures. Emotions have merged here with their verbal interpretation. But every feeling (pain and joy) has many shades that need to be brought together through a range of expressive means. Emotions - expanded states - begin to rely on a scale of expressive means that related to different areas of musical language. Baroque strives for a certainty of emotional states. An intonation vocabulary is formed in Baroque, also appear intonation formulas, which go into genre designation, for instance as ,lamento" [1].

The intonation vocabulary was formed in the conditions when all, both recognized singers and ordinary people sang. It was peculiar to this era that allowed everyone to be on a same music wave, in a same musical stream, because it had a common repertoire, teams, and coryphaeuses $[3,11-13]$. Interpretation of baroque music is a continuous creativity, because it is unique in each performance, every time the emotion is relived and created directly at the moment of performance. The inseparable link between the performance process and reproducing images in imagination is approved. We can view and evaluate this by listening to the performance. If the vocal art of the baroque is constantly reproduced, then we transfer this property to our time.

The experience of our contemporaries is significant and valuable to us. Therefore, considering the vision of the features of baroque performance by contemporary singers, we present an analysis of the Cleopatra's aria interpretation from G.F. Handel's opera „Julius Caesar” by different contemporary singers.

With the obligatory observance of performance rules of baroque vocal music, concerning the correct distribution of dynamics, ornamentation of reprise, characteristics of sound producing and other, the personal interpretation of each performer is unique and each carries its shades of emotional and energetic content. And it is interesting for the listener to contemplate the unique, individually valuable creativity of the artist, who, while adhering to the inviolable canons, creates his own, new. When analyzing the performance of this piece of music by different singers, we can see the use of different technical and artistic methods. For example, Joyce Di Donato, an American opera singer, presents a very bright performance, with a greater emphasis on emotions of anger and a passionate desire for revenge in the recitative and middle section of the 
aria, portraying the main character of Cleopatra, the queen, who has now been captured and does not want to put up with such a fate.

But in the interpretation of Patricia Petibo, a French opera singer, we can feel a deeper and more subtle penetration into the emotion of helplessness and despair of the main character Cleopatra, when she (in the same story context) is weak, powerless and does not know what is next, and she does not expect help from anyone. This is especially evident in the first and third sections of the aria. And the singer bestows the angry active middle section with a more virtuoso character, which creates an image of determination rather than revenge.

Thus, different performers highlight different shades of character in the figurative sphere, creating a holistic image of the character, show the hero from different angles, reveals the essence of the image in different ways.

In the absence of specialized baroque singing schools in our country, we seek for literature and find experience in baroque master classes. Such master classes in Ukraine are conducted by experts who come from other countries. But without the singer's previous independent work, without theoretical knowledge of the rules and requirements for baroque singing, without the proper condition of the singer, this valuable and rare information from master classes of masters can be worse absorbed, it may even be such that the student will not be able to understand.

In developing my understanding of baroque vocal performance some advices played an important role, that I heard while attending the baroque master class of a soloist of the Warsaw Opera House Olga Pasichnyk in Kyiv, and also taking part in it. Work has been done on many numbers from G.F. Handel's opera „Acis and Galatea”. Therefore, this article will outline some of these guidelines [2].

The first unusual condition for me to perform was singing accompanied by a harpsichord, which was tuned in a lower order than we used to hear the accepted standard of sound $\mathrm{a}^{1}=440 \mathrm{~Hz}$. The height standards used in earlier times differ from the present up to the whole tone. When performing ancient music, modern authentic artists use different standards. For baroque music, the standard $\mathrm{a}^{1}=415 \mathrm{~Hz}$ is common (about half a ton below the standard piano „la") [6]. This tuning of the harpsichord and also the cello was in keeping with the authentic tradition of performing this music, forcing me as a performer to adapt immediately to these new conditions, trying to maintain vocal and technical coordination. This turns out to be one of the aspects that modern 
performers have to face. The first thing a contemporary artist faces is that his attitude changes to the idea that he needs to readjust his hearing. It is very difficult to accept this tradition, because the modern singer has a constant muscle memory for sound and vocal coordination. The new attitude to sound, its height, must be connected with the feeling of a certain emotional state, the theory of affects that arises from the needs of performance [5, 286-287].

O. Pasichnyk encouraged the work of the performer with the score. The singer needs to know what is going on in the chord vertical, because in the baroque there are fragments when voice music material is not the main, but is only a counterpoint to the material that the orchestra plays. And therefore a competent singer-singer should understand when he needs to become only one of the instruments of the orchestra to create a coherent authentic sound, and not to be a soloist every second, when, for example, the main musical material sounds exactly in the orchestra, and the vocalist must at that moment fit into a certain harmony as one of the non-leading strings [2].

Particular emphasis was placed on the importance of the text, the content. All apogeeatures, ornaments in the melody are uniquely conditioned by the context, nature and color of the word, and all trills must "fit the word" [2]. The singer's attention was drawn to the nature of the performance, depending on the character and context: contemplative or efficient. And the manner of sound production is chosen according to this [5, 295-296]. In baroque vocal music there are sudden jumps of melody, then in high, then in low register. Historically, this phenomenon is due to the fact that in high tessitura it is not possible to understand the text clearly, and if the word itself is important, the same text is repeated again in a lower register for listeners to hear the text [2]. Also some time was dedicated to the purity of vowel sounds.

Baroque music is very rich in various artistic and expressive means. There is the phenomenon of ,abruption" [2], when in a melody a phrase or several phrases in a row suddenly break off, and each carries its own meaning, it creates a shock effect, for example, on the word ,rock”, „fate”. However, the pause is not a stop, exactly it is the pause that ,propels the dramatic action forward" [2]. Recitatives should include intonation similar to spoken language, for example, ascending intonation, which creates the effect of interrogation - a query, without allowing a great vibration of the voice. The expressive intonation of „esclamazione" is also important [5, 295-296]. If the melody develops in variations, or simply repeats the 
same phrase, it cannot be performed in the same way, the emergence of new sequences must necessarily be motivated, dynamics must be increased, evolved emotionally and in sound, , another, higher temperature of the word should be manifested" [2]. When the melody goes down, the sound cannot be dissolved, so to speak, it is necessary to present the sound "not by trapeze, but by a cone", and rotate it over and over so that the sound does not fall [2].

In the form of Da Capo in the reprise there must be some changes in the melody, some decoration, ornamentation [5, 304]. Such tradition is typical for arias of Handel, who constantly communicated with prominent singers, and therefore fully utilized the virtuoso capabilities of the singing voice $[4,107]$. Such variations can be created according to the harmony in the bass, avoiding the unison with the bass, avoiding parallel quints. The cadence at the end of the arias must have some specific meaning, it may be either bravura or soothing, but not just a virtuoso exercise of the singer [5, 296]. And among the ornaments of melody the apogeeatures should sound longer, and in cadences the trill should be sung faster, with an aspiration for tonic. And especially in such coloraturas it is important to distribute the breath and the musical support in the phrase to one strong beat, as a base station, and all other notes should ,fly without gravity” [2], passages with sixteenth notes should to be sung in completely different technique, with a light sound, „like a butterfly, as a flag in the wind, no more" [2]. And at the same time a singer should make sure that the bell sensation is constantly in front of him, without opening his mouth wide, we should „not to let the melody go, we should lead it by our ear", and ,the voice is constantly twisted into a resonant point". I will quote other phrases about passages that inspired me greatly: „the face reflects the light”; ,passages should be sung without trying, without clamping your body as if you were playing in the sand" [2].

As for the interpretation of different images, different characters, O. Pasichnyk said that the singer should let everything through the figure, which he currently becomes on stage. Sometimes, when we do not see such character traits in ourselves, it is worth looking at those around us and finding inspiration for our acting pursuits. It is not always necessarily to portray noble heroes, it is necessary to portray characters as they are. It is not necessarily to refine everyone, to look for beauty. They are as they are, and there is beauty. We have to sing very theatrically, we cannot sing in a same way, everything should sparkle [2]. 
It is impossible to exaggerate the importance and value of becoming a singer with the help of the baroque repertoire. It is similar to the mandatory program requirement to play the pieces of music by J.S. Bach for instrumentalists (for instance, pianists, violinists, and especially important is the sonatas and partitas performance for violin solo). And so as well as vocalists. Such program requirements are created to foster a culture of professional sound-producing by a musician, which can be successfully applied to another repertoire of the following musical styles. It is important for vocalists to associate the sound of their voice with the characteristics of the piece of music being performed. More than once I have already convinced myself from my personal experience that exactly thanks to the baroque repertoire the voice sounds quite different than with another repertoire; voice begins to play with many other timbre colors and shades, perhaps even those that have not yet been used by this singer earlier, new voice control capabilities appear. And this state of the vocalist is like a miracle.

Baroque sound production aims at creating a "pure tone", and it is not about sound hight, but about the qualitative characteristic of sound. This elaborate work teaches the singer to control all kinds of performance coordination more thoroughly. The conductor teaches the singer to enrich the palette, suggests what you have in your voice, what you can draw, which colors you have: watercolors, oil and gouache. All that we, the singers-performers, are trying to learn, to find out, is all in order to get more colors in the voice when performing.

The choice of dynamics in pieces of music depends on the emotional state of the hero. It should be noted that „,crescendo" is not an increase in the strength and loudness of sound, but first of all it is the development of sound by concentration and accumulation of sound energy, by addition of more overtones. Such music instructs the vocalist to find a sense of constant circulation, a continuous movement of the sound stream, which begins even before the actual beginning of sound (phonation), and the vocalist joins this air wave and adheres to it throughout the singing process. This phenomenon can be compared to the vibration start on a violin, when the oscillatory movement of the left hand of the violinist, which creates the vibration, begins in advance, before the bow touches the string. That is the performance, giving to the listener a sense of human heart beating continuously.

With the baroque repertoire, it is very noticeable how the singer can better control his vocal breathing: it should not be held down by force, 
tension, but on the contrary - we should let the note go, let it feel „gravitation". The main task of breathing is not to allow any change in the vocal coordination that is already created, but to maintain harmony and balance, a single air column.

Thus, the baroque repertoire instructs the performer how to develop the range of voice in the upper tessitura precisely through the search for a sense of comfort, tranquility and an awareness of the ability to control their instrument - voice. And overcoming technical issues in the process of becoming a vocalist allows him to express himself more clearly and vividly in the artistic and figurative spheres.

Especially among recitatives in baroque music the theatrical aspect of acting is shown clearly and brightly, the expressiveness of the phrases is presented due to the greater approximation to the linguistic intonations of the question/answer, the re-affirmation with already new degree of emotion, triumph, pacification or anger, indignation, jealousy, resentment , helplessness, disgust, devastation. These are the typological characteristics of human sensations that the Baroque uses to sculpt an image.

Conclusions. Artistic principles of baroque vocal art are generalized, considering both means of musical expression and vocal technique. A comparative analysis of the Cleopatra's aria interpretation from G.F. Handel's opera „Julius Caesar” by different contemporary singers is conducted. The performance practice has been revealed and the key elements of expressiveness of baroque singing have been described on the basis of Olga Pasichnyk's baroque master class. The importance and value of becoming a modern singer thanks to the baroque repertoire is determined, which teaches to achieve the greatest expressiveness through the use directly the embodiment of musical affects that form the basis of baroque music. However, not all voices can sing this music due to the fact that for its high-quality performance and finding by a performer the state of comfort and possession of your voice, you need firstly to learn a large amount of information about the rules of Baroque music, to immerse in its atmosphere. A lot of valuable information on this topic exists in foreign languages - these are scientific works and video materials. It is an intellectual work that inevitably takes time.

The prospects of this investigation. The results of the study can be used by students of Conservatory in solo and chamber singing classes, as well as by vocalists performing in their concert and competition events. Prospects for further deepening into the issues of this topic may be directed to a more advanced research genre structure, up to a monograph. 


\section{Список використаних джерел і літератури:}

1. Арнонкур Н. Музыка языком звуков, путь к новому пониманию музыки. Москва : Музыка, 1987. 190 с.

2. Барокове мистецтво. Бароковий майстер-клас О.І. Пасічник : рукопис. Київ, 2018.

3. Барбье П. Венеция Вивальди. Музыка и праздники эпохи барокко. СанктПетербург : Изд. Ивана Лимбаха, 2009. 280 с.

4. Бейшлаг А. Орнаментика в музыке. Москва : Музыка, 1978. 318 с.

5. Луцкер П.В., Сусидко И.П. Итальянская опера XVIII века. Москва : Гос. инст. искусствознания, 1998. Ч. І. 440 с.

6. Muse Baroque: URL: http://www.musebaroque.fr/instrument-diapason (дата зверненя: 12.02.2010).

\section{References:}

1. Arnonkur, N. (1987). Music in the language of sounds, the way to a new understanding of music. Moskva: Muzyka [in Russian].

2. Pasichnyk, O.I. (Eds.). (2018). Baroque master-class by O.I. Pasichnyk. Kyjiv [in Ukrainian].

3. Barb'e, P. (2009). Venice Vivaldi. Baroque music and holidays. Sankt-Peterburg: Izd. Ivana Limbaha [in Russian].

4. Bejshlag, A. (1978). Ornamentation in music. Moskva: Muzyka [in Russian].

5. Lucker, P.V., Susidko, I.P. (1998). Italian opera of the $18^{\text {th }}$ century. Moskva: Gos. inst. Iskusstvoznanija [in Russian].

6. Muse Baroque, (2010) Retrieved from http://www.musebaroque.fr/instrumentdiapason [in English]. 